\title{
Collagenous colitis diagnosed by endoscopically induced mucosal tears
}

\author{
Yasutoshi Shiratori, Katsuyuki Fukuda
}

Department of

Gastroenterology, St Luke's International Hospital, Tokyo, Japan

\section{Correspondence to} Dr Yasutoshi Shiratori, shiraya@luke.ac.jp

Accepted 10 May 2019

\section{DESCRIPTION}

Collagenous colitis (CC) is widely recognised as a cause of chronic diarrhoea. CC is sometimes diagnosed with cat scratch sign found during colonoscopy. ${ }^{1}$ On the other hand, no abnormality is observed in more than $80 \%$ of cases; hence, the diagnosis of CC cannot be made without biopsy. We report a case of a patient with mucosal tears occurring during colonic endoscopy, who was successfully diagnosed with CC by histopathological analysis.

A 70-year-old man who had been taking lansoprazole for gastro-oesophageal reflux disease visited our outpatient department, complaining of chronic watery diarrhoea that had lasted for more than a month. Colonoscopy was performed to diagnose the cause of symptoms. Although the colonic mucosa appeared normal, several longitudinal mucosal tears suddenly occurred in the left colon (figure 1). The patient had no abdominal symptoms. The mucosal tears were speculated to be cat scratch sign. Biopsies of these lesions revealed chronic inflammation in the lamina propria on staining with haematoxylin-eosin and thickening of the subepithelial collagen bands on staining with Masson's trichrome (figure 2). The patient was therefore diagnosed with CC.

CC occurs due to the ingestion of drugs such as proton pump inhibitors and non-steroidal anti-inflammatory drugs; also its prevalence is increasing. ${ }^{2}$ CC, in this case, was considered to be triggered by lansoprazole and the mucosal tears by the intestinal pressure increase due to air supply during colonoscopy. Procedure-related perforation was reported in CC; so cautious air insufflation is necessary. ${ }^{4}$ In terms of location, both right and left biopsies were frequently positive in CC. ${ }^{5}$ The patient's symptoms of diarrhoea resolved soon after he discontinued lansoprazole.

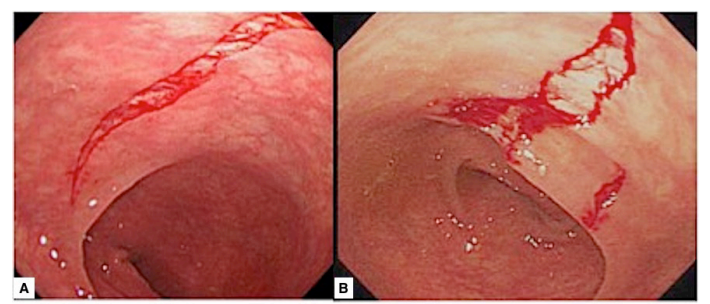

Figure 1 Several longitudinal mucosal tears occurring just during colonic endoscopy.

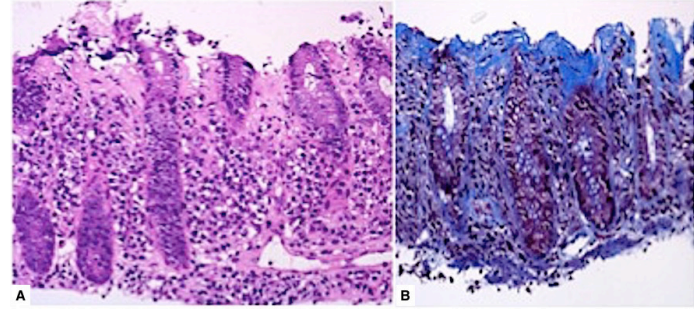

Figure 2 Biopsies of mucosal tears revealed chronic inflammation in the lamina propria on staining with $\mathrm{H} \& \mathrm{E}$ and thickening of the subepithelial collagen bands on staining with Masson's trichrome.

\section{Learning points}

- We experienced mucosal tears occurring just during colonic endoscopy.

- Mucosal tears are findings that lead to endoscopic diagnosis of collagenous colitis.

- For patients with macroscopic findings at the time of colonoscopy, there is slightly increased risk of colonic perforation.

Cautious air insufflation at a time of colonoscopy is necessary in patients with macroscopic findings and suspected CC.

Contributors YS performed the colonic endoscopy. YS and KF managed the patient and wrote this article.

Funding The authors have not declared a specific grant for this research from any funding agency in the public, commercial or not-for-profit sectors.

Competing interests None declared.

Patient consent for publication Obtained.

Provenance and peer review Not commissioned; externally peer reviewed.

\section{REFERENCES}

1 Baudet JS, Aguirre-Jaime A. Factors related to the development of cat scratch colon during colonoscopy. Endoscopy 2013;45:582-4.

2 Bohr J, Tysk C, Eriksson S, et al. Collagenous colitis: a retrospective study of clinical presentation and treatment in 163 patients. Gut 1996:39:846-51.

3 Münch A, Aust D, Bohr J, et al. Microscopic colitis: Current status, present and future challenges: statements of the European Microscopic Colitis Group. J Crohns Colitis 2012;6:932-45.

4 Kane JS, Rotimi O, Ford AC. Macroscopic findings, incidence, and characteristics of microscopic colitis in a large cohort of patients from the United Kingdom Scandinavian. J Gastroentero/ 2017;52:988-94.

5 Marlicz W, Skonieczna-Żydecka K, Yung DE, et al. Endoscopic findings and colonic perforation in microscopic colitis: A systematic review. Dig Liver Dis 2017;49:1073-85. 
Images in...

Copyright 2019 BMJ Publishing Group. All rights reserved. For permission to reuse any of this content visit https://www.bmj.com/company/products-services/rights-and-licensing/permissions/

BMJ Case Report Fellows may re-use this article for personal use and teaching without any further permission.

Become a Fellow of BMJ Case Reports today and you can:

- Submit as many cases as you like

- Enjoy fast sympathetic peer review and rapid publication of accepted articles

Access all the published articles

- Re-use any of the published material for personal use and teaching without further permission

For information on Institutional Fellowships contact consortiasales@bmjgroup.com

Visit casereports.bmj.com for more articles like this and to become a Fellow 